\title{
Persepsi Masyarakat Terhadap Pembangunan Infrastruktur Penataan Kawasan Pesisir Pantai Gurindam 12
}

\author{
Alfi Husni ${ }^{1}$ Rianto $^{2}$ Anggi Dwidhika ${ }^{3}$ \\ ${ }^{1}$ Sosiologi, Sekolah Tinggi IImu Sosial dan IImu Politik Raja Haji \\ Email: alfi@stisipolrajahaji.ac.id \\ ${ }^{1}$ Sosiologi, Sekolah Tinggi Ilmu Sosial dan IImu Politik Raja Haji \\ Email: rianto@stisipolrajahaji.ac.id \\ ${ }^{1}$ Sosiologi, Sekolah Tinggi Ilmu Sosial dan Ilmu Politik Raja Haji \\ Email: anggidwidikhaputra@gmail.com
}

\begin{abstract}
Perception is the act of compiling, recognizing, and interpreting information in order to provide an overview and understanding of the environment. This can be seen from the existence of opinions for managing and utilizing available resources to improve the quality of people's lives. Resources are not unlimited in quantity and quality, while the need for and use of these resources is increasing due to the increase in population and their needs. This study aims to determine how the community's perceptions of the infrastructure development of the coastal area of the Gurindam 12 studies in the community of haji agus salim street RT 05 RW IV. namely positive perceptions and negative perceptions. In this study the authors used a purposive sampling technique. The selected informants were 10 people from the haji agus salim street community RT 05 RW 04 . This study used qualitative data analysis to provide a clear, logical and accurate picture of the results of data collection. Based on the results of interviews and observations made, it can be seen that the positive perception obtained is that the community is very supportive of this development, because this development can become the number 1 center in Tanjungpinang City and can reduce congestion, and it is hoped that it will become a new tourist destination in Tanjungpinang City. The city of Tanjugpinang, while the negative perception of the existence of this development, the community feels disturbed because most people whose livelihoods are fishermen complain and air pollution, dust from hoarding and loud engine noise also disturbs the residents around here.
\end{abstract}

\section{Keywords : Public Perception; Development; Coastal Area}

\begin{abstract}
Abstrak. Persepsi merupakan tindakan menyusun, mengenali, dan menafsirkan informasi guna memberikan gambaran dan pemahaman tentang lingkungan hal ini dapat dilihat dari adanya pendapat-pendapat untuk mengelola dan memanfaatkan sumber daya yang tersedia untuk dapat meningkatkan mutu kehidupan masyarakat. Sumber daya bukan tidak terbatas baik jumlah maupun kualitasnya, sedangkan kebutuhan dan pemanfaatan sumber daya tersebut semakin meningkat akibat meningkatnya jumlah penduduk serta kebutuhannya. Penelitian ini bertujuan untuk mengetahui bagaimana persepsi masyarakat terhadap pembangunan insfrastruktur penataan kawasan pesisir pantai gurindam 12 studi pada masyarakat jalan haji agus salim RT 05 RW IV, dalam pembahasan ini, hal-hal yang dilihat dan dianggap dapat melihat kedisiplinan kerja pegawai terdiri dari 2 faktor yaitu persepsi positif dan persepsi negatif. Dalam penelitian ini penulis menggunakan teknik sampel purposive sampling. Informan yang ditetapkan adalah 10 orang masyarakat jalan haji agus salim RT 05 RW 04 Penelitian ini menggunakan analisis data kualitatif untuk memberikan gambaran yang jelas, logis dan akurat mengenai hasil pengumpulan data. Berdasarkan dari hasil wawancara dan hasil observasi yang dilakukan maka dapat diketahui bahwa persepsi positif yang di dapat adalah masyarakat sangat mendukung dengan adanya pembangunan tersebut, karena pembangunan ini dapat menjadi pusat nomor 1 di Kota Tanjungpinang serta dapat mengurangi kemacetan, dan diharapakan menjadi destinasi wisata baru di Kota Tanjugpinang, sedangkan persepsi negatif dengan adannya pembangunan ini masyarakat merasa tengganggu karena kebanyakan masyarakat yang mata pencaharian nelayan mengeluhn dan polusi udara debu-debu tanah dari penimbunan dan suara mesin yang keras juga mengganggu penduduk sekitar sini.
\end{abstract}

Kata Kunci : Persepsi Masyarakat; Pembangunan; Kawasan Pesisir 


\section{PENDAHULUAN}

Pembangunan merupakan upaya secara sadar untuk mengelola dan memanfaatkan sumber daya yang tersedia untuk dapat meningkatkan mutu kehidupan masyarakat. Sumber daya bukan tidak terbatas baik jumlah maupun kualitasnya, sedangkan kebutuhan dan pemanfaatan sumber daya tersebut semakin meningkat akibat meningkatnya jumlah penduduk serta kebutuhannya. Upaya pembangunan daerah akan dimanfaatkan aspek-aspek yang secara ekonomi berpotensi untuk dikembangkan. Potensi ekonomi dalam kerangka pembangunan daerah dapat diartikan sebagai kesanggupan, kekuatan, dan kemampuan di bidang ekonomi yang dimiliki oleh suatu daerah untuk membangun daerah tersebut. Proses pembangunan tidak terjadi begitu saja, tetapi harus diciptakan melalui intervensi pemerintah, melalui kebijakan-kebijakan yang mendorong terciptanya proses pembangunan. Dalam pelaksanaan pembangunan ada tiga pertanyaan dasar yang perlu dijawab, Pertama, pembangunan perlu diletakkan pada arah perubahan struktur. Kedua, pembangunan perlu diletakkan pada arah pemberdayaan masyarakat dan memberikan ruang dan kesempatan yang lebih besar kepada rakyat banyak untuk berpartisipasi secara aktif dalam pembangunan. Dan ketiga, pembangunan perlu diletakkan pada arah koordinasi lintas sektor mencakup program pembangunan antar sektor, pembangunan antar daerah, dan pembangunan khusus.(Sumodiningrat, 2001).

Salah satu solusi pembangunan yang sudah lama dilakukan oleh Negara- Negara yang memiliki garis pantai, mereka telah menggunakan reklamasi pantai untuk menambah ruang menjawab persoalan kebutuhan lahan industri, dan permukiman seperti Negara Belanda, Cina, Jepang, Korea Selatan dan Singapura. Pembangunan melalui reklamasi pesisir pantai sering menimbulkan masalah lingkungan, termasuk hilangnya keanekaragaman hayati pantai, penurunan kualitas air laut dan juga penurunan produksi ikan tangkap. Untuk itu, di beberapa Negara membuat aturan penanganan kontrol yang lebih ketat untuk reklamasi (Ramaniya, 2017).

Beberapa contoh penelitian terdahulu yang serupa dengan pembangunan infrastruktur yang ada di beberapa wilayah di Indonesia adalah :

Penelitian sejenis telah dilakukan oleh Chairil Budiarto Amiuza (2014). Penelitiannya merupakan penelitian yang memadukan pendekatan kualitatif dan kuantitatif. Hasil penelitian ini menunjukkan bahwa Karakter Kota Dalam Persepsi Masyarakat yaitu : (1) menurut pendapat masyarakat Kota Probolinggo, ada 24 ciri lingkungan kota yang mendukung / sesuai dengan karakter kota maupun yang merusak/tidak sesuai dengan karakter kota. Kedua puluh empat ciri lingkungan kota yang terdiri dari 16 elemen atau ciri dari lingkungan yang sesuai dengan karakter kota dan 8 elemen atau ciri lingkungan kota yang tidak sesuaai dengan karakter kota tersebut. (2) bahwa menurut pendapat masyarakat Kota Probolinggo yang digali dengan pendekatan kualitatif, ada 24 ciri lingkungan kota yang mendukung/sesuai dengan karakter kota maupun yang merusak/tidak sesuai dengan karakter kota. Masyarakat menilai bahwa bangunan-bangunan bersejarah yang ada di Kota Probolinggo serta suasana alamiah seperti pepohonan, ruang terbuka hijau atau taman-taman merupakan elemen-elemen kota yang memberikan kontribusi besar terhadap terbentuknya karakter kota Probolinggo. Sebaliknya, kehadiran rukoruko yang marak di Kota Probolinggo, mal-mal besar, papan-papan reklame, keberadaan PKL yang tidak tertata di wilayah kota, serta permukimanpermukiman kumuh dinilai oleh masyarakat sebagai elemen-elemen yang tidak sesuai dengan karakter Kota Probolinggo. Disamping itu, kesan visual yang negatif terhadap kemacetan lalu lintas yang sering terjadi di beberapa lokasi di Kota Probolinggo, banyaknya pengemis yang tersebar di Kota Probolinggo dinilai masyarakat sebagai merusak karakter Kota Probolinggo secara keseluruhan. Hal ini menunjukkan bahwa untuk mempertahankan karakter Kota Probolinggo sebagai kota bersejarah sekaligus kota pantai perlu upaya untuk mengendalikan elemen elemen ataupun ciri-ciri lingkungan visual yang berkecendrungaan untuk merusak karakter kota, dan disisi lain diupayakan untuk mempertahankan atau bahkan meningkatkan eksitensi elemen-elemen kota atau ciri-ciri lingkungan visual kota yang dianggap oleh masyarakat sebagai pembentuk karakter kota.

Penelitian sejenis telah dilakukan oleh Roni Oktora (2011). Penelitian ini termasuk tipe penelitian deskriptif kualitatif, adapun uraian deskriptif yang dimaksudkan adalah mendeskripsikan persepsi pemilik lahan dan masyarakat Kota Solok terhadapa pembangunan jalan lingkar utara Kota 
Solok yang menggunakan teknik pengumpulan data dengan cara kuesioner kepada 100 orang responden. Berdasarkan hasil penelitian persepsi masyrakat terhadap pembangunan jalan lingkar maka dapat ditarik kesimpulan bahwa kebijakan pembangunan jalan lingkar ini mendapat dukungan mayoritas masyarakat, pembangunan jalan lingkar utara berpotensi mempercepat perkembangan kawasan utara Kota Solok, tingkat pemanfaatan lahan dan nilai lahan di sekitar jalan lingkar utara bisa meningkat, dan pembangunan jalan lingkar akan lebih memperlancar transportasi yang melewati kota solok. Akan tetapi perlu di cermati tentang dampak negatif yang mungkin ditimbulkan (http://eprints.undip.ac.id/31476/1/Tesis Roni Oktora.pdf).

Penelitian sejenis yang telah dilakukan oleh Asmayanti Sudirman (2018). Pengaruh Reklamasi Pantai Terhadap Kondisi Sosial Ekonomi Masyarakat Kota Lasusua (Studi Kasus Kelurahan Lasusua dan Desa Ponggiha).Hasil penelitian ini menunjukkan bahwa : (1) Pengaruh tata guna lahan akibat adanya reklamasi pantai sangat memberikan pengaruh besar bagi Kelurahan Lasusua dan Desa Ponggiha di mana pada tahun 2006 tata guna lahan di lokasi penelitian hanya didominasi oleh ruang terbuka hijau, namun setelah reklamasi sampai dengan tahun 2017 kawasan sekitar reklamasi mengarah kepada kegiatan-kegiatan non-pertanian. Presepsi masyarakat mengenai pengaruh yang terjadi akibat adanya reklamasi pantai telah memberikan pengaruh negatif dan pengaruh positif, di mana adanya reklamasi ini memudahkan aksesibilitas dan menciptakan lapangan kerja bagi sebahagian orang, dan memberikan dampak negatif bagi beberapa nelayan dan petani. (2) Analisis penerapan uji korelasi terhadap faktor yang berpengaruh terhadap sosial ekonomi masyarakat, keterkaitan antara reklamasi pantai terhadap tingkat pendidikan, tingkat pendapatan, kelembagaan, sarana ekonomi dan kesempatan kerja memiliki hubungan yang kuat atau berpengaruh (http://repositori.uin-alauddin.ac.id/view/creators/Sudirman=3AAsmayanti=3A=3A.html).

Dari ketiga contoh penelitian terdahulu tersebut maka dapat dianalisakan bahwa pembangunan infrastruktur terkait dengan persepsi masyarakat ada yang beranggapan positif maupun negatif, masyarakat yang menilai negatif beralasan bahawa pembangunan mengakibatkan berubahnya karakter kota, sedangankan masyarakat yang sangat mendukung dan beranggapan positif sangat berkontribusi dalam program pemerintah untuk pembangunan infrastruktur, dan berpengaruh terhadap sosial ekonomi masyarakat dalam keterkaitannya dengan pembangunan infrastrukur tersebut.

Berdasarkan dari analisa tersebut jika dibedakan dengan penelitian tentang Pembangunan Infrastruktur Kawasan Pesisir Pantai Kota Tanjungpinang ini, maka dapat dilihat bahwa pembangunan tersebut berada di kota yang dikelilingi pulau-pulau kecil, sedangkan dari ketiga contoh penelitian terdahulu diatas dapat dilihat bahwa pembangunan itu dilakukan di kota yang dikelilingi pulau-pulau besar. Maka pembangunan Infrastruktur Penataan Kawasan Pesisir Pantai Gurindam 12 Kota Tanjungpinang ini tentu dapat meningkatkan produktifitas terhadap kelancaran transportasi serta perkembangan kawasan pesisir pantai Kota Tanjungpinang. Maka dengan adanya studi ini diharapkan dapat mengetahui persepsi masyarakat terhadap Pembangunan Infrastruktur Penataan Kawasan Pesisir Pantai Gurindam 12 Kota Tanjungpinang, guna mengetahui sampai sejauh mana tingkat manfaat dan pengaruh yang terjadi agar dapat mengantisipasi permasalahan yang dapat terjadi dan dapat dijadikan bahan pertimbangan dalam pelaksaan pembangunan yang akan datang.

Dengan adanya rencana Pembangunan Infrastruktur Penataan Kawasan Pesisir Pantai Gurindam 12 Kota Tanjungpinang ini, mendorong terjadinya perubahan guna lahan di sepanjang kawasan pembangunan. Pada saat ini beberapa lahan sekitar lokasi Pembangunan Infrastruktur Penataan Kawasan Pesisir Pantai Gurindam 12 Kota Tanjungpinang dari semula merupakan lahan perdagangan kaki lima nantinya dibangun lahan parkir dipelabuhan dengan luas lahan 2 sampai 3 hektar dan dipastikan dapat menampung 2 sampai 3 ribu kendaraan. Untuk kawasan hijau disekitar area reklamasi tidak akan diganggu gugat sama sekali bahkan kawasan hijau tersebut ditata ulang sedemikian rupa agar dapat terlihat lebih menarik dan dapat dijadikan kawasan wisata dan akan ditambahkan ruang hijau terbuka multifungsi nantinya seluas 3 hektar juga dari Tanjung Buntung hingga Tugu Pensil. Untuk struktur Pembangunan Infrastruktur Penataan Kawasan Pesisir Pantai 
Gurindam 12 Kota Tanjungpinang sendiri agan beragam, salah satunya jalan dari kawasan depan SMAN 5 hingga kawasan Lantamal IV juga dibangun jembatan sehingga tidak merusak kawasan perkampungan Teluk Keriting. Kemudian juga akan dibuat dinding penahan gelombang dari jembatan 1 hingga ke Pantai Impian yang dapat difungsikan juga sebagai jalan.

\section{METODE PENELITIAN}

Jenis penelitian dalam penelitian ini adalah deskriptif kualitatif. Menurut Mukthar (2013: 10) metode penelitian deskriptif kualitatif adalah sebuah metode yang digunakan peneliti untuk menemukan pengetahuan terhadap penelitian pada satu wilayah tertentu. Jenis penelitian deskriptif kualitatif juga dipilih kerena peneliti ingin menganalisa secara mendalam tentang objek yang diteliti yaitu bagaimana persepsi masyarakat setempat terhadap proses Pembangunan Infrastruktur Penataan Kawasan Pesisir Pantai Gurindam 12 Kota Tanjungpinang tersebut.

Penarikan sampel yang digunakan dalam penelitian ini adalah teknik Purposive Sampling. Purposive sampling adalah pemilihan informan yang ada dalam posisi terbaik dan memiliki tujuan dalam memberikan informasi yang dibutuhkan. Adapun dalam penelitian ini sampel yang di ambil adalah masyarakat yang tinggal di RT 05 RW IV serta masyarakat yang menjadi Nelayan dan PKL di wilayah tersebut.

\section{HASIL PENELITIAN DAN PEMBAHASAN}

Persepsi merupakan tindakan menyusun, mengenali, dan menafsirkan informasi guna memberikan gambaran dan pemahaman tentang lingkungan hal ini dapat dilihat dari adanya pendapat-pendapat untuk mengelola dan memanfaatkan sumber daya yang tersedia untuk dapat meningkatkan mutu kehidupan masyarakat. Sumber daya bukan tidak terbatas baik jumlah maupun kualitasnya, sedangkan kebutuhan dan pemanfaatan sumber daya tersebut semakin meningkat akibat meningkatnya jumlah penduduk serta kebutuhannya. Maka pembangunan Infrastruktur Penataan Kawasan Pesisir Pantai Gurindam 12 Kota Tanjungpinang ini tentu akan meningkatkan produktifitas terhadap kelancaran transportasi serta perkembangan kawasan pesisir pantai Kota Tanjungpinang. Maka dengan adanya ini diharapkan dapat mengetahui persepsi masyarakat terhadap Pembangunan Infrastruktur Penataan Kawasan Pesisir Pantai Gurindam 12 Kota Tanjungpinang, guna mengetahui sampai sejauh mana tingkat manfaat dan pengaruh yang terjadi agar dapat mengantisipasi permasalahan yang akan terjadi dan dapat dijadikan bahan pertimbangan dalam pelaksaan pembangunan yang akan datang.

\section{Persepsi Positif}

Persepsi yang menggambarkan segala pengetahuan (tahu tidaknya atau kenal tidaknya) dan tanggapan yang diteruskan dengan upaya pemanfaatannya. Hal itu akan di teruskan dengan keaktifan atau menerima dan mendukung terhadap objek yang di persepsikan. Masyarakat juga diharapkan mengetahui segala manfaat terhadap Pembangunan Insfrastruktur Penataan Kawasan Pesisir Pantai Gurindam 12.

\section{a. Masyarakat setuju dengan Pembangunan Insfrastruktur Penataan Kawasan Pesisir Pantai Gurindam 12 Kota Tanjungpinang.}

persepsi di sini adalah cenderung posisif dimana masyarakat sangat mendukung dan memberikan persepsi positif terhadap pembangunan insfrastruktur penataan kawasan pesisir pantai gurindam 12. Persepsi positif menunjukkan bahwa dengan adanya pembangunan ini membuka banyak peluang untuk berjualan dan tentunya yang di harapkan menjadi destinasi wisata baru di Kota Tanjungpinang dan dapat mengurangi kemacetan di kawasan tersebut. Proyek gurindam ini akan dibangun jalan sepanjang $43 \mathrm{~km}$ dari pulau marina hingga tepilaut dan dompak. Dan dipastikan itu benar-benar sesuai dengan aturan dan harus bermanfaat bagi peningkatan kesejahteraan masyarakat.

Persepsi positif yang menggambarkan segala pengetahuan dan tanggapan dan kemudian di teruskan dengan upaya pemanfaatannya. Hal itu dapat menerima dan mendukung terhadap 
pembangunan insfrastruktur penataan kawasan pesisir pantai gurindam, perbaikan pada sektor infrastruktur tentunya dapat mendorong minat investasi asing dan domestik. Pembangunan infrastruktur merupakan pilar menentukan kelancaran arus barang, jasa, manusia, dan informasi dari satu zona ke zona lainnya. Penataan kasawan pantai pesisir gurindam 12 salah satu proyek pembangunan yang tujuannya adalah pemanfaatan jangka panjang di semua aspek. Selain mengurangi kemacetan dikemudian hari juga dapat menjadikan Tanjungpinang semakin berdaya tarik tinggi serta tentunya peningkatan perekonomian daerah, pembangunan ini kita lakukan demi menambah daya tarik dalam semua hal.

b. Manfaat Pembangunan Insfrastruktur Penataan Kawasan Pesisir Pantai Gurindam 12 Kota Tanjungpinang.

Pemanfaatan dalam pembangunan ini untuk meningkatkan pertumbuhan ekonomi dalam suatu daerah, tentunya akan membuka peluang untuk menjadi wirausaha karna akan banyak kegiatan yang akan tumbuh karna hadirnya kawasan ini. Kawasan ini akan menjadi investasi jangka panjang bagian daerah dengan cepat selesainya proyek ini maka semakin rapi dan tertata dan diharapkan menjadi laluan yang tepat agar setiap proses pembangunan dapat berjalan dengan baik. Selain infrastruktur memiliki peranan positif terhadap pertumbuhan ekonomi dengan jangka panjang namun juga menciptakan lapangan kerja dan akan mendukung peningkatan efisiensi dan produktivitas sektor-sektor terkait. Infrastruktur sepertinya menjadi jawaban dari kebutuhan masyarakat yang ingin mendorong pertumbuhan ekonomi, dengan membantu penanggulangan kemiskinan, meningkatkan kualitas hidup, mendukung tumbuhnya pusat ekonomi. Maka dapat dianalisa bahwa teori persepsi positif oleh Irwanto sangat cocok untuk menggambarkan segala manfaat positif yang dirasakan oleh terhadap Pembangunan Insfrastruktur Penataan Kawasan Pesisir Pantai Gurindam 12 ini.

\section{c. Meningkatkan daya tarik pengunjung / wisatawan lokal}

Pembangunan Insfrastruktur Penataan Kawasan Pesisir Pantai Gurindam 12 ini selain untuk meningkatkan daya tarik pengunjung juga dapat mengurangi kemacetan dan meningkatkan perekonomian masyarakat. Sehingga pendekatan sosiologis tentang daya tarik dengan melihat hubungan antara kekuatan atau potensi pariwisata, yaitu orang, kelompok, organisasi badan usaha kepariwisataan dan masyarakat serta objek dan daya tarik untuk masyarakat.Pembangunan ini beradapatasi terhadap semua tuntutan perubahan dengan selalu mendengar suara dari berbagai pihak yang berkepentingan khususnya masyarakat yang memiliki persepsi yang berbeda-beda. Yang mengacu pada sesuai dengan teori persepsi positif di dalam persepsi mengandung suatu proses dalam diri untuk mengetahui dan mengevaluasi sejauh mana kita mengetahui orang lain. Pada proses ini kepekaan dalam diri seseorang terhadap lingkungan sekitar mulai terlihat. Cara pandang akan menentukan kesan yang dihasilkan dari proses persepsi. Proses interaksi tidak dapat dilepaskan dari cara pandang atau persepsi satu individu terhadap individu yang lain, sehingga memunculkan apa yang dinamakan persepsi masyarakat. Persepsi masyarakat akan menghasilkan suatu penilaian terhadap sikap. Perilaku dan tindakan seseorang di dalam kehidupan bermasyarakat. Sehingga dapat disimpulkan proses dari sebuah pembangunan gurindam 12 sangat positif meningkatkan daya tarik pengunjung. Ini terbukti munculnya tempat-tempat baru untuk makan dan minum yang berada di sekitar kawasan berupa café atau kedai kopi dengan nuansa kekinian.

\section{d. Meningkatkan perekonomian Pedagang Kaki Lima}

Pedagang Kaki Lima (PKL) adalah pedagang yang melakukan usaha perdagangan menggunakan sarana usaha bergerak, seperti becak, gerobak, mobil, dan lainnya, maupun sarana tidak bergerak seperti kios kecil, serta menempati tempat-tempat umum seperti trotoar di jalan raya, taman kota, dan lain-lain. Sehingga dengan adanya pembangunan insfrastruktur penataan kawasan pantai pesisir gurindam 12 dapat meningkatkan perkonomian Pedagang Kaki Lima di wilayah tersebut yang berdampak begitu positif, karena usaha Pedagang Kaki Lima merupakan salah satu jalan untuk memenuhi kebutuhan hidup, sulitnya lapangan pekerjaan yang tersedia bagi masyarakat membuat usaha kecil ini menjadi bagian yang tak terpisahkan dari kehidupan 
keseharian masyarakat. Muncul pedagang kaki lima disekitar kawasan merupakan pelepas dahaga bagi PKL karena kawasan akan ramai dikunjungi oleh masyarakat sehingga akan berpengaruh untuk daya beli masyarakat.

\section{Persepsi Negatif}

Persepsi yang menggambarkan segala pengetahuan (tahu tidaknya atau kenal tidaknya) dan tanggapan yang tidak selaras dengan obyek yang dipersepsi. Hal itu akan kepasifan atau menolak dan menetang terhadap objek yang di persepikan. Untuk mengetahui fasilitator dalam persepsi masyarakat terhadap Pembangunan Insfrastruktur Penataan Kawasan Pesisir Pantai Gurindam 12 dapat dilihat dari sub indikator sebagai berikut :

\section{a. Aktivitas masyarakat terganggu}

Dampak negatif pemasalahan pembangunan yang terjadi merupakan dampak terhadap pembangunan yang dilakukan telah menimbulkan kerusakan, sehingga pembangunan yang dilakukan berdampak terhadap kerusakan disekitar wilayah pesisir seperti misalnya pencemaran perairan terus berlangsung sehingga membuat para nelayan terganggu dengan segala aktifitas yang mereka lakukan pada setiap hari. Sehingga masyarakat merasakan perubahan lingkungan yang disebabkan adanya reklamasi pembangunan tersebut yang membuat sebagian lingkungan laut menjadi rusak dan membuat sebagian masyarakat yang bermata percaharian sebagai nelayan menjadi terganggu. Setiap rencana pembangunan pusat kegiatan, permukiman, dan infrastruktur yang akan menimbulkan secara langsung dan tidak langsung telah mempengaruhi mata pencaharian Nelayan. Hal ini disebabkan oleh adanya gangguan terhadap lingkungan tempat hidup ikan baik setelah terjadinya pembangunan maupun selama kegiatan pembangunan berjalan. Sehingga dengan adanya penimbunan menyebabkan ikan-ikan menjauh dan tidak dapat mendekat, Tetapi bahwa nelayan masih banyak yang melakukan penangkapan ikan meski hasil yang peroleh telah mengalami penurunan. Maka dapat disimpulkan persepsi negatif dan diberikan oleh masyarakat bahwa masyarakat merasakan adanya perubahan terhadap Pembangunan Insfrastruktur Penataan Kawasan Pesisir Pantai Gurindam 12 ini merugikan para nelayan yang dimana lokasi nelayan mencari nafkah hilang menjadi tercemar.

b. Dampak bagi kesehatan masyarakat terhadap segala aktifitas dalam Pembangunan Insfrastruktur Penataan Kawasan Pesisir Pantai Gurindam 12.

Masyarakat di sekitar sini juga banyak mengeluhkan kondisi infrastruktur khususnya infrastruktur jalan yang saat ini dirasakan sangat mengganggu dan mempengaruhi kesehatan masyarakat secara umum, hal ini dapat diketahui mengakibatkan polusi udara yang mengganggu masyarakat setempat dan pengguna jalan, adapun polusi yang dihasilkan dari pembangunan tersebut adalah debu dari tanah yang digunakan untuk menimbun kawasan pesisir. Masyarakat merasakan tercemarnya polusi udara dan suara kendaraan proyek yang setiap harinya beroperasi hingga malam yang begitu sangat mengganggu waktu istirahat akibat adanya Pembangunan Insfrastruktur Penataan Kawasan Pesisir Pantai Gurindam 12.

\section{KESIMPULAN}

Berdasarkan hasil penelitian yang dilakukan dengan menganalisa data -data, keterangan dan penjelasan yang diperoleh dapat diambil kesimpulan dapat diketahui bahwa persepsi masyarakat terhadap pembangunan insfrastruktur pentaan kawasan pesisir pantai gurindam 12 ada yang positif dan ada yang negatif.

Kemudian dalam indikator positif, masyarakat sangat mendukung dengan adanya pembangunan tersebut, karena pembangunan ini dapat menjadi pusat nomor 1 di Kota Tanjungpinang serta dapat mengurangi kemacetan, dan diharapakan menjadi destinasi wisata baru di Kota Tanjugpinang, karena perubahannya sangat bagus dapat meningkatakan daya tarik wisatawan yang datang ke Kota Tanjungpinang. Setelah proyek ini selesai masyarakat sekitar bisa membuka usaha atau berjualan di kawasan wisata baru itu, untuk meningkatkan perekonomian dan kesejahteraan masyarakat. 
Sementara itu indikator negatif, dengan adannya pembangunan ini masyarakat merasa tengganggu karena kebanyakan masyarakat yang mata pencaharian nelayan mengeluh dengan hasil tangkapan berkurang akibat pembangunan tersebut. Karena mereka susah untuk menyondong udang biasa nelayan mendapatkan $3 \mathrm{~kg}$ udang setiap hari, namun setelah proyek itu berja;an hasil tangkapan tidak sampai $1 \mathrm{~kg}$ per hari, sementara masalah yang kedua yaitu dampak bagi kesehatan dimana mereka merasa tengganggu dengan pembangunan ini karena polusi udara debu-debu tanah dari penimbunan dan suara mesin yang keras juga mengganggu penduduk sekitar sini.

\section{DAFTAR PUSTAKA}

Arsyad, Lincolin, 1999. Pengantar Perencanaan dan Pembangunan Ekonomi Daerah, Edisi Pertama, Yogyakarta: BPFE.

Budiharsono, Sugeng. 2001. Teknik Analisis Pembangunan Wilayah Pesisir dan Lautan. Jakarta: PT. Pradnya Paramita.

Chairil, Budiarto Amiuza, 2014. Karakter Kota Dalam Persepsi Masyarakat (Studi Kasus Kota Pantai Probolinggo)

Dahuri, Rokhmin, 2IV. Pengelolaan Sumber Daya Wilayah Pesisir dan Laut Secara Terpadu, Jakarta: Penerbit Pradnya Paramita.

Hardjowigeno, Sarwono dan Widiatmoko. (2011). Evaluasi Kesesuaian Lahan dan Perencanaan Tataguna Lahan. Yogyakarta: Gadjah Mada University Press.

Hadinoto, Kusudianto. 1996. Perencanaan Pembangunan destinasi Pariwisata. Universitas Indonesia. Maryati, dan Suryawati, 2003. Sosiologi 1. Jakarta: Erlangga.

Meleong, L.J. 2014. Metodologi Penelitian Kualitatif. Cetakan ke 32, PT. RemajaRosdakaraya, 2014.

Mulyana, Deddy. 2013. Metodologi Penelitian Kualitatif. Cetakan ke 8. Bandung: PT. Remaja Rosdakaraya.

Ramaniya, Arya. 2017. Dampak Reklamasi Terhadap Kualitas Air Dan Sosial Ekonomi Masyarakat Nelayan Di Sekitar Kawasan Reklamasi Teluk Jakarta. Sekolah Pascasarjana Institute Pertanian Bogor

Sugiyono. 2009. Metode Penelitian Kuantitatif, Kualitatif dan R\&D. BandungAlfabeta.

Soekanto, Soerjono. 2009. Sosiologi Suatu Pengantar. Jakarta Pt Dunia Pustaka Jaya.

Sumodiningrat. 2001. Menuju Swasembada Pangan : Revolusi hijau II. RBI

Zuriah, Nurul. 2009. Metodologi Penelitian Sosial : Teori Dan Aplikasi. Jakarta :

PT. Bumiaksara.

http://eprints.undip.ac.id/31476/1/Tesis Roni Oktora.pdf

http://repositori.uin-alauddin.ac.id/view/creators/Sudirman=3AAsmayanti=3A=3A.html 